Dr GORAN LATINOVIĆ, docent

Univerzitet u Banjaluci

Banjaluka, Bulevar vojvode Petra Bojovića 1a

UDK 327(497.1:485)"1941/1945"(093.2)

341.7(497.1:485)"1941/1945"(093.2)

94(497.1:485)"1941/1945"(093.2)

\title{
JUGOSLOVENSKO-ŠVEDSKI ODNOSI 1941-1945.
}

\begin{abstract}
APSTRAKT: Deklaracija o trgovini između Kraljevine Srbije i Kraljevine Švedske potpisana je 1907. godine. Švedska je od 1917. štitila srpske interese u Osmanskom Carstvu, što je bio dodatni razlog za odluku srpske vlade da otvori poslanstvo u Stokholmu, koje je bilo aktivno do 1920. Šesnaest godina kasnije jugoslovensko poslanstvo je ponovo otvoreno, a 1937. potpisan je jugoslovensko-švedski ugovor o trgovini i plovidbi. Švedska je otvorila poslanstvo u Beogradu 1939, koje je zatvoreno dvije godine kasnije. Jugoslovensko-švedski odnosi održavani su i tokom Drugog svjetskog rata. Tekst je napisan na osnovu izvora koji se čuvaju u Arhivu Srbije i Arhivu Jugoslavije u Beogradu i Švedskom nacionalnom arhivu (Riksarkivet) u Stokholmu, kao i na osnovu literature na srpskom, engleskom i švedskom jeziku.
\end{abstract}

KLJUČNE RIJEČI: Jugoslavija, Švedska, Norveška, NDH, Drugi svjetski rat

Kapitulacijom jugoslovenske vojske 17. aprila 1941. godine, okupacijom i podjelom njene teritorije, Jugoslavija nije prestala da postoji kao država. Odlaskom u izbjeglištvo, Vlada Kraljevine Jugoslavije produžila je svoju međunarodnu politiku, ali u znatno težim uslovima. Ona je u emigraciji održavala diplomatske odnose sa Britanijom, SAD, SSSR, Poljskom, Čehoslovačkom, Španijom, Portugalom, Turskom, Švajcarskom, Vatikanom, Švedskom, Norveškom, Danskom i francuskom vladom u Višiju. Međutim, kad je Danska priznala Nezavisnu Državu Hrvatsku, proglašenu 10. aprila 1941. godine, jugoslovenska vlada je 24. maja 1941. prekinula diplomatske odnose sa danskom vladom. ${ }^{1}$

Jugoslovenska vlada bila je obavještena već 1940. godine da je u jugoslovenskom poslanstvu u Stokholmu prisutna netrpeljivost po nacionalnoj osnovi, koja je slomom Kraljevine Jugoslavije i proglašenjem Nezavisne

${ }^{1}$ Dušan Plenča, Međunarodni odnosi Jugoslavije u toku drugog svjetskog rata, Beo$\operatorname{grad} 1962,47$. 
Države Hrvatske postala još izraženija. Trojica Hrvata: Milorad Stražnicki, ${ }^{2}$ Nikola Nadić i Krsto Jandrijević, i četvorica Srba: Ivan Šajković, Milovan Milovanović, Dragomir Bogić i Vučković, nisu imali usaglašene međuljudske i međunacionalne odnose. Nije blagonaklono gledano ni na poslanikovo ponašanje tokom ratne 1941. godine, koji je uživao u Stokholmu, igrajući tenis i golf. ${ }^{3}$ Dodatni problem bila je skupoća u Švedskoj, zbog čega je osoblje poslanstva tokom 1941. godine tražilo povišicu od 30\%. ${ }^{4}$ Milorad Stražnicki pisao je 25. jula 1941. jugoslovenskoj vladi u Londonu da je nezadovoljan svojim statusom u jugoslovenskom poslanstvu u Stokholmu i da je izložen šikaniranju. On je tri dana kasnije podnio ostavku na mjesto jugoslovenskog poslanika u Stokholmu, otputovao u Zagreb i stavio se na raspolaganje Nezavisnoj Državi Hrvatskoj. ${ }^{5}$ Nakon njegovog odlaska, dužnost otpravnika poslova vršio je Vladislav M. Marković, ${ }^{6}$ sve dok 23 . septembra 1942. dužnost jugoslovenskog poslanika u Stokholmu nije preuzeo Aleksandar Avakumović. ${ }^{7}$ Marković je u julu 1941. obavijestio svoju vladu da švedski vojni krugovi smatraju da bi za ovu zemlju bilo najbolje ako bi i Njemačka i Sovjetski Savez iz rata izašli veoma oslabljeni, a da bi bilo opasno ako bi poslije rata Englezima bila prepuštena prevlast u Evropi. Marković je dodao da Švedska nastoji da izbjegne i najmanji incident sa Njemačkom i da joj zbog toga čini velike ustupke, tako da njemački vojni transporti i materijal za Finsku neometano prolaze kroz švedske teritorijalne vode. ${ }^{8}$

U stvari, Švedska nije imala veliki strateški značaj ni za Njemačku, niti za Sovjetski Savez i zapadne saveznike. Za velike sile veću stratešku vrijednost imale su Danska, Norveška i Finska, koje su zbog toga i bile uvučene u rat. Švedska je snabdjevala Njemačku željeznom rudom i drvnom građom i dopuštala je tranzit njemačkih trupa preko svoje teritorije, čime je

${ }^{2}$ Milorad Stražnicki, rođen 1879. u Križevcima, doktorirao je na Pravnom fakultetu u Zagrebu, gdje je bio profesor do 1929, kada prelazi u jugoslovensku diplomatiju. Bio je poslanik u Buenos Ajresu, Hagu i Stokholmu. Po proglašenju Nezavisne Države Hrvatske 1941. priključio se ustaškom režimu. Arhiv Jugoslavije (AJ), 334 Ministarstvo inostranih poslova Kraljevine Jugoslavije (UO-PO)-195-518.

${ }^{3}$ Arhiv Srbije (AS), Bezbednosno-informativna agencija (BIA), z. 107, o. 1/23. Na ustupljenom dokumentu zahvaljujem dr Radmili Radić, naučnom savetniku Instituta za noviju istoriju Srbije.

${ }_{5}^{4} \mathrm{AJ}, 334(\mathrm{UO}-\mathrm{PO})-94-302$.

${ }^{5}$ Jugoslavenske vlade u izbjeglištvu 1941-1943: dokumenti, priredio Bogdan Krizman, Beograd - Zagreb 1981, 168-169.

${ }^{6}$ Vladislav M. Marković rođen je 1898. u Zaječaru, diplomirao je prava u Lozani, a od 1922. bio je zaposlen u jugoslovenskom Ministarstvu inostranih dela. Službovao je u Parizu, Kairu i Moskvi, vršeći razne dužnosti, a od 16. maja 1941. bio je savjetnik u Stokholmu. Za jugoslovenskog poslanika u Lisabonu postavljen je aprila 1944. AJ, 334(UO-PO)-169-492.

${ }^{7}$ AJ, 103-78-307.

${ }^{8}$ AJ, 382-1-1. 
bila „neutralni saveznik“ Trećeg rajha. Tokom rata, švedska privreda je potpuno zavisila od trgovinske razmjene sa Njemačkom, a Sovjetski Savez i zapadni saveznici smatrali su da ni okupacija Švedske, niti njen ulazak u rat, ne bi imali suštinski značaj za savezničku pobjedu. ${ }^{9}$

Švedski poslanik u Beogradu, Knut Folke Malmar, ${ }^{10}$ javio je 16. aprila 1941. švedskoj vladi da je Njemačka priznala Nezavisnu Državu Hrvatsku, a dva dana kasnije pisao je da se sa raznih strana interesuju kakav stav će Švedska zauzeti povodom proglašenja NDH. On je obrazložio da švedske kompanije imaju izvjesni interes u NDH i da Švedska ne bi trebalo da ponovi grešku koju je učinila u vezi sa Slovačkom, te da treba da prizna NDH. Izgleda da je on namjeravao da bude švedski poslanik u Zagrebu. Vlasti Nezavisne Države Hrvatske, čija je zvanična politika bila da trećinu Srba treba ubiti, trećinu protjerati, a trećinu prevesti na rimokatolicizam i pohrvatiti, u više navrata su tražile i od švedskih vlasti da priznaju hrvatsku nezavisnost. Hrvatski šef diplomatije, Mladen Lorković, pisao je tim povodom švedskoj vladi 17. juna 1941. Uprava kompanije Svenska Kullagerfabriken iz Geteborga, koja je u NDH izvozila kuglične ležajeve, pisala je 21. jula iste godine švedskom Ministarstvu spoljnih poslova, $u$ nadi da će priznati hrvatsku nezavisnost. Švedski konzul u Zagrebu, Ragnar Volin, obavijestio je Stokholm da niz država ima diplomatska predstavništva u hrvatskoj prestonici. On je novembra 1941. ponovio da bi Švedska trebalo da prizna Hrvatsku, a o tome je bilo govora i u martu iduće godine. ${ }^{11}$ Milorad Stažnicki, generalni direktor ekonomskih i konzularnih poslova $u$ hrvatskom Ministarstvu spoljnih poslova, zalagao se u februaru 1943. za uspostavljanje čvršćih hrvatsko-švedskih odnosa. Nešto kasnije, Volin je javio švedskoj vladi da je Stražnicki rekao da će se lično angažovati na približavanju NDH i Švedske. ${ }^{12}$ Hrvatske vlasti su 3. aprila 1943. ponovo tražile od Volina da njegova zemlja prizna NDH. Ipak, s obzirom na to da Njemačka nije pokrenula pitanje priznanja Hrvatske, švedska vlada nije namjeravala da to učini. $^{13}$

${ }^{9}$ Wilhelm M. Calgren, Swedish Foreign Policy during the Second World War, London \& Tonbridge 1977, 225-228.

${ }^{10}$ Knut Karl Folke Malmar rođen je 1890. u Karlshamnu, gdje mu je otac bio gradonačelnik. Nakon završenih pravnih studija, zaposlio se 1917. u švedskom Ministarstvu spoljnih poslova, gdje je kasnije bio i načelnik pravnog odjeljenja. Službovao je u švedskom poslanstvu u Helsinkiju i učestvovao u radu nekoliko međunarodnih konferencija. Bio je švedski poslanik u Pragu (1937-1939) i Beogradu (1939-1941). Umro je 1947. u Stokholmu. - Stig Jägerskiöld, Malmar, Knut Karl Folke, Svenskt biografiskt lexikon (under redaktion av Birgitta Lager-Kromnow), 24, Stockholm 1982-1984, 734-735.

${ }^{11}$ Riksarkivet (Švedski nacionalni arhiv) (RA), Utrikesdepartmentet (Ministarstvo inostranih poslova Kraljevine Švedske) UD (1920 års dossiersystem), HP 893, I.

${ }^{12}$ RA, UD (1920 års dossiersystem), HP 2812, VII.

${ }^{13}$ AJ, Poslanstvo Kraljevine Jugoslavije u Stokholmu 382-1-2. 
Iako Švedska nije priznala NDH, ona je sa njom održavala ekonomske odnose. Preduzeće Original-Odhner A. B. iz Geteborga pisalo je 5. septembra švedskom Ministarstvu spoljnih poslova u vezi sa izvozom kalkulatora u NDH preko Mađarske. Pet dana kasnije, Volin je obavijestio svoju vladu da je hrvatski Zavod za spoljnu trgovinu dao načelnu dozvolu za trgovinsku razmjenu sa Švedskom. On je istakao da Švedska izvozi u Hrvatsku jedino kuglične ležajeve i da je trenutna vrijednost tog izvoza oko 20.000 švedskih kruna, a da bi mogla da dostigne oko 300.000 kruna. Iz Stokholma je odgovoreno da $u$ vezi sa tim treba imati u vidu i politički kontekst. Posljednjeg dana oktobra 1941. Državna industrijska komora Švedske obratila se Ministarstvu spoljnih poslova i obavijestila ga da je posljednjih godina Švedska svoju potrebu za kudeljom podmirivala iz Jugoslavije i Mađarske, ali da je uvoz sa tog područja otežan. ${ }^{14}$ Hrvatske vlasti su 18. novembra 1941. odobrile izvoz u Švedsku tri vagona zaklanih ćurana, u zamjenu za metalske proizvode i mašine. Istog mjeseca, Volin je hrvatskim vlastima dostavio spisak robe koja bi mogla biti predmet švedsko-hrvatske trgovinske razmjene. Od Hrvatske je tražen izvoz poljoprivrednih proizvoda, a uvoz industrijskih proizvoda. ${ }^{15}$ Volin i Lorković razgovarali su o unapređenju švedsko-hrvatskih odnosa, a hrvatski šef diplomatije naglasio je da je Švajcarska neutralna zemlja, ali da održava ekonomske odnose sa NDH. Volin je primjetio da je švedski interes u NDH posebno izražen u industriji šibica. U stvari, za uspostavljanje boljih ekonomskih odnosa sa Hrvatskom zalagale su se one švedske firme koje su do 1941. godine imale tržište na tom području. Međutim, otežavajuća okolnost bio je transport robe preko Njemačke, za šta je bilo potrebno imati posebnu dozvolu. ${ }^{16}$

Ukupan hrvatski uvoz iz Švedske 1941. godine iznosio je $9.470 \mathrm{~kg} \mathrm{u}$ vrijednosti od 866.932 hrvatske kune. Uglavnom se radilo o kugličnim ležajevima (6.577 kg, 182.899 kuna). Istovremeno, hrvatski izvoz u Švedsku iznosio je $109.250 \mathrm{~kg}$ u vrijednosti od 1.785 .302 kune. Najveći dio tog izvoza činile su štavljene kože (95.000 kg, $1.408 .200 \mathrm{kuna}) .{ }^{17}$ Prema tome, švedski trgovinski bilans sa NDH 1941. godine bio je izrazito pasivan.

Prva srpska fabrika aviona u Beogradu i firma Ikarus A. D. iz Zemuna uoči rata 1941. godine kupile su materijale od švedske firme See Fabriks A. B. iz Sandvikena, ali nisu uspjele da ih transportuju u Jugoslaviju. Jugoslovensko poslanstvo u Stokholmu tražilo je u julu 1941. instrukcije od jugoslovenske vlade u izbjeglištvu, jer su Nijemci zahtjevali da im Šveđani isporuče tu robu. Iz Londona je javljeno da su materijali plaćeni i da pripadaju

\footnotetext{
${ }^{14}$ RA, UD (1920 års dossiersystem), HP 2812, VII.

${ }^{15} \mathrm{RA}, \mathrm{UD}(\mathrm{KZ}), \mathrm{E} 1: 14$.

${ }^{16}$ RA, UD (1920 års dossiersystem), HP 2812, VII.

${ }^{17}$ Isto.
} 
jugoslovenskom vazduhoplovstvu i da ne mogu biti predati Nijemcima, odnosno firmama koje su ih kupile, jer je zemlja okupirana i te firme su pod njemačkom upravom. Takođe je javljeno da materijali treba da ostanu $u$ magacinu ili da budu prodati, ali ne silama Osovine. ${ }^{18}$

Utisci izvjesnog Forsberga sa njegovog putovanja kroz Srbiju krajem avgusta 1941, sigli su i u Stokholm. On je primjetio da su izjave njemačkih vojnika u vezi sa nesigurnom situacijom i bojazni od gerilskog ratovanja, jednodušne, jer svoje komentare obično završavaju riječima „Die Serben sind Teufel“ („Srbi su đavoli“). U Stokholm je početkom oktobra 1941. stigao izvještaj iz Rima, u kojem se kaže da između Zagreba i Sarajeva živi oko milion i po Srba, tj. „neprijatelja“, i da su ustaški zločini doveli do „srpskog komunističkog ustanka“. ${ }^{19}$

Hrišćanska zajednica mladih ljudi, sa sjedištem u Stokholmu, pružala je pomoć jugoslovenskim zarobljenicima u Njemačkoj, zbog čega je jugoslovensko poslanstvo u decembru 1941. izrazilo zahvalnost njenom generalnom sekretaru Hugu Ceder-Grenu. ${ }^{20}$

Vladislav M. Marković je početkom 1942. izvjestio jugoslovensku vladu u izbjeglištvu da je u Stokholm doputovao jedan švedski državljanin, koji je 25 godina živio u Beogradu, i da mu je rekao da Srbi vjeruju u pobjedu Jugoslavije i da su veoma ogorčeni na Hrvate zbog ustaških zločina nad srpskim civilima. Marta 1942. u Stokholmu su boravili zagrebački teniseri Josip Palada i Dragutin Mitić, koji su u naselju Alvik odigrali nekoliko mečeva sa švedskim teniserima, a zatim su otišli u Geteborg, pa u Berlin. Osoblje jugoslovenskog poslanstva razgovaralo je sa njima o situaciji u Zagrebu. ${ }^{21}$

Švedski publicista Emil Langlet, koji je govorio srpski jezik i bio dobar poznavalac prilika u Jugoslaviji, posjetio je Beograd u maju 1941. i napisao reportažu za švedski radio, koja zbog procijenjene delikatnosti sadržaja nije emitovana, već je objavljena u časopisu Tiden u februaru 1942. Jugoslovensko poslanstvo u Stokholmu hvalilo je njegov rad na suzbijanju njemačke propagande u Švedskoj, posebno nakon što je 1943. godine objavio brošuru o njemačkim zločinima u Jugoslaviji, koja je štampana u 3.500 primjeraka. $^{22}$ Iste godine, Sigurd Tulberg objavio je, pod pseudonimom Stenli Vud, knjigu Blod, skräck och tårar: Två års "nyordning" i Jugoslavien (Krv, strah i suze: dvije godine „novog poretka“ u Jugoslaviji), kojom je upoznao švedsku javnost o dešavanjima u Jugoslaviji od 1941. do 1943. godine. Njegova knjiga ima izrazit antinacistički karakter i bliska je stavovima

\footnotetext{
${ }^{18}$ AJ, 103-78-307.

${ }^{19}$ RA, UD (1920 års dossiersystem), HP 562, XV.

${ }^{20}$ AJ, 382-1-6.

${ }^{21}$ AJ, 382-1-3.

${ }^{22}$ AJ, 382-1-7.
} 
jugoslovenske vlade $u$ izbjeglištvu. On je napisao, pored ostalog, da je u NDH ubijeno preko 600.000 Srba, a kad se tome dodaju i ljudski gubici na drugim područjima, dolazi se do podatka od preko milion žrtava „novog poretka" u Jugoslaviji. ${ }^{23}$

Službenik jugoslovenskog poslanstva u Stokholmu Krsto Jandrijević sreo je 23. septembra 1942. u stokholmskoj ulici Birger Jarl bivšeg službenika jugoslovenske vlade Ivana Kolaka. Njih dvojica su otišli u restoran Anglais. Kolak je ispričao Jandrijeviću da je poslije sloma Kraljevine Jugoslavije otputovao u Zagreb, gdje je postavljen za šefa Kabineta ministra spoljnih poslova NDH Mladena Lorkovića. U Hrvatskoj vlada uvjerenje da će Njemačka izgubiti rat zbog ruskog otpora, rekao je Kolak. Dodao je kako je oduševljen Stokholmom, posebno osvjetljenjem i snabdjevanjem grada. ${ }^{24}$

Nekoliko dana nakon što je 12. septembra 1942. ukazom kralja Petra II Karađorđevića postavljen za jugoslovenskog poslanika u Švedskoj, Aleksandar Avakumović ${ }^{25}$ stigao je u Stokholm i preuzeo novu dužnost. Po dolasku u švedsku prestonicu, Avakumović je imao dva razgovora sa generalnim sekretarom Ministarstva spoljnih poslova Kraljevine Švedske, Buhemanom. On je tražio od Avakumovića da Vlada Kraljevine Jugoslavije obavijesti švedsku vladu o njegovom postavljenju u Stokholm, ali samo u svojstvu otpravnika poslova. Zbog njemačkog pritiska, još je traženo da se dotadašnji otpravnik poslova više ne pominje na listi diplomatskog osoblja, jer Nijemci nisu željeli da se u Švedskoj povećava broj lica na diplomatskoj listi iz okupiranih zemalja. ${ }^{26}$ Dotadašnji otpravnik poslova Vladislav M. Marković otišao je u London.

Tokom službovanja u Stokholmu, Avakumović je jugoslovenskoj vladi u izbjeglištvu slao izvještaje koji se odnose na stanje u Švedskoj i na pisanje tamošnje štampe, a posebno lista Ny Dag, koji je bio organ Komunističke partije. Avakumović je 11. januara 1943. svojoj vladi prenio vijest, koju je dobio od švedskog poslanika u Budimpešti, da se stanovništvo Bosne i Hercegovine smanjilo za jednu četvrtinu i da postoji nastojanje među Srbima u Bosni da izbjegnu u Srbiju, radi spasavanja života. U jednom od izvještaja koje je poslao jugoslovenskom premijeru Slobodanu Jovanoviću, jugoslovenski poslanik u Stokholmu napisao je da se u februaru 1943. susreo

${ }^{23}$ Stanley S. Wood, Blod, skräck och tårar: Två års "nyordning" i Jugoslavien, Stockholm 1943, 31.

${ }^{24}$ Jugoslavenske vlade u izbjeglištvu 1941-1943: dokumenti, 400-401.

${ }^{25}$ Aleksandar Avakumović je rođen 1896. u Zemunu. Doktorirao je na ekonomskofinansijskoj grupi Pravnog fakulteta u Subotici. U Ministarstvu inostranih dela radio je od 1920, službujući na raznim dužnostima u Bukureštu, Budimpešti, Sofiji, Rimu i Madridu, a zatim kao poslanik u Bukureštu, odakle je premješten za poslanika u Stokholmu. Poslije Drugog svjetskog rata živio je u Londonu. - AJ, 334(UO-PO)-133-456.

${ }^{26}$ AJ, 382-1-8. 
sa jednim čovjekom koji je tokom zime 1942-1943. dva mjeseca proveo putujući po Evropi, posjetivši i Jugoslaviju. On je rekao Avakumoviću da u Beogradu vlada neviđena bijeda i da je smrtnost među djecom nesrazmjerno velika. On je dodao da je tokom 1942. godine u Beogradu i okolini ubijeno preko 30.000 ljudi. Avakumović je 18. juna 1943. obavijestio Jovanovića da ima informaciju od jednog lica da u Zagrebu vlada strah od onoga što će nastati „kad se vrate Srbi“. ${ }^{27}$

Švedski vicekonzul u Beogradu, Gesta Matijas Enlund, rekao je u februaru 1943, tokom svoje posjete Budimpešti, da se pod utiskom ruskih pobjeda na Istočnom frontu mijenja raspoloženje $u$ Beogradu. Iako je njemački režim i dalje čvrst, kod stanovništva Beograda obnavlja se smisao za optimizam. On je procijenio da bi se situacija mogla odvijati tako da će Nijemci biti primorani da napuste zemlju, a tokom prelaznog perioda, prije nego što bi general Mihailović i trupe koje ga podržavaju krenuli naprijed, srpski partizani, koji biju svoju bitku u Srbiji, mogli bi zauzeti glavni grad, u kojem postoje velike simpatije za komunizam. ${ }^{28}$

Aleksandar Avakumović je 16. decembra 1943. poslao izvještaj jugoslovenskom premijeru i ministru spoljnih poslova Božidaru Puriću, u kojem je naveo da su posljednja dešavanja u Jugoslaviji izazvala nepovoljan utisak u Švedskoj, gdje postoji mišljenje da tamo bjesni građanski rat, čije će se posljedice osjećati godinama poslije zaključenja mira. U švedskoj vladi smatraju da se jedino Titov pokret bori protiv okupatora, a ranije je postavljeno pitanje: da li je, poslije svega što se desilo, moguće da Srbi i Hrvati ostanu u jednoj državi? ${ }^{29}$ Pet dana kasnije, jugoslovenski poslanik izvjestio je da su švedsko-njemački odnosi pogoršani, da je u Švedskoj pozvan veći broj rezervista i da su preduzete mjere za odbijanje iznenadnog njemačkog napada. On je 22. decembra 1943. javio Puriću da je, u skladu sa instrukcijama koje je ranije dobio od njega, preduzeo korake da švedska vlada odredi svog predstavnika pri jugoslovenskom dvoru. Avakumović je od švedske vlade dobio načelno povoljan odgovor, s tim da u decembru budu utvrđeni detalji. Međutim, tog mjeseca švedske vlasti stavile su do znanja da treba sačekati sa tim dok se situacija u Jugoslaviji „ne razbistri““. ${ }^{30}$

Šef švedske diplomatije Kristijan Ginter i jugoslovenski poslanik u Stokholmu, Aleksandar Avakumović, razgovarali su 4. januara 1944. o situaciji u Evropi. Ginter je rekao da je pogriješio kad je predvidio da će rat biti okončan u januaru 1944. i dodao da glavne teškoće za Evropu dolaze tek po

${ }^{27}$ AJ, 103-6-58.

${ }^{28}$ RA, UD (1920 års dossiersystem), HP 562, XV.

${ }^{29}$ Jugoslovenske vlade u izbeglištvu 1943-1945: dokument, priredio Branko Petranović, Beograd - Zagreb 1982, 267-269.

${ }^{30}$ AJ, 103-180-631. 
okončanju rata. On se interesovao i za prilike u Jugoslaviji, a Avakumović, nemajući novih informacija, odgovarao je uopšteno. ${ }^{31}$ Jugoslovenski poslanik u Stokholmu javio je svojoj vladi 4. februara 1944. da u Švedskoj postoji strah od Rusije, što je možda i najvažniji činilac u švedskom gledanju na spoljnopolitičke probleme. ${ }^{32}$

Avakumović je 18. februara 1944. obavijestio Purića da švedski novinar Krister Jederlund pokušava da stupi u neposredni kontakt sa generalom Dragoljubom Mihailovićem. Jugoslovenski poslanik u Stokholmu imao je informaciju da je Jederlund njemački agent i da bi bilo kakav kontakt sa njim mogao da kompromituje ugled srpskog generala. Avakumović je pokušao da obavijesti generala Mihailovića, ali nije bio siguran da će njegova poruka doći do vođe jednog dijela srpske gerile. Stoga je zamolio Purića da on upozori komandanta Jugoslovenske vojske u otadžbini. ${ }^{33}$ Nije poznato da li je do susreta između generala Mihailovića i Jederlunda došlo tokom njegovog boravka u Srbiji u proljeće 1944, ali je švedski novinar 14. aprila iste godine u listu Stockholms Tidningen objavio veoma afirmativan tekst u kojem je Mihailovićev boravak u šumama vezao za slobodarsku tradiciju srpskog naroda. Jederlund je napisao da Mihailović želi da sačuva Srbe od daljeg stradanja, jer tvrdi da je oko milion Srba izgubilo život u ratu, pa se ponašao pasivno, odbijajući i činjenicu da su ga zbog toga napustili i Britanci, koji su podržali Tita. ${ }^{34}$ Švedski vicekonzul u Beogradu Enlund poslao je 16. juna 1944. izvještaj u Stokholm, u kojem je rekao da je bombardovanje Beograda i drugih gradova u Srbiji, tokom kojeg su naročito stradali civili, dovelo do ozlojeđenosti protiv zapadnih saveznika. Beograd je praktično dva mjeseca bio mrtav grad. On je procijenio da će komunisti izvući najveću korist od bombardovanja, jer Rusi ne vrše vazdušne napade. Dodao je i to da je mogućnost saradnje Titovih i Mihailovićevih trupa veoma mala, a u prilog tome govore i nastojanja Titovih ljudi da optuže Mihailovića da sarađuje sa Nijemcima, što nije tačno. ${ }^{35}$

Inače, švedska štampa je pisala i o partizanima predvođenim Josipom Brozom Titom i Komunističkom partijom Jugoslavije, i o generalu Dragoljubu Mihailoviću, koji je imao podršku jugoslovenske vlade u izbjeglištvu i čiji su četnici takođe okarakterisani kao borci protiv okupatora. Pisano je i o partizansko-četničkoj saradnji. ${ }^{36}$ Sa izuzetkom komunističkog

${ }^{31}$ Isto.

${ }^{32}$ AJ, 382-1-1.

${ }^{33}$ AJ, 382-1-7.

${ }^{34}$ Slobodan Nešović, Svet o nama 1941-1945, I-III, Beograd 1983, III, 162-167.

${ }^{35}$ RA, UD (1920 års dossiersystem), HP 563, XVI.

${ }^{36}$ Lj. Mlađenović, Švedska štampa o NOB-u u Jugoslaviji 1941-1943, Novinarstvo, XXV, 1-2, Beograd 1989, 53-55. 
lista Ny Dag, čiji su komentari bili krajnje ideološki i koji je imao veoma ograničen uticaj na javno mnjenje, švedska štampa se uglavnom trudila da bude neutralna. Gunar Milern, novinar lista Aftonbladet, napisao je 6. januara 1942. da se u Srbiji vodi rat svih protiv sviju. On je naveo da se „srpski problem" sastoji od pet faktora: 1. njemačke okupacione trupe, 2. predsjednik srpske vlade general Nedić i njegove trupe, 3. nacionalisti predvođeni generalom Mihailovićem, 4. sovjetska uprava u Užicu, i 5. operišuće bande više razbojničkog karaktera. ${ }^{37}$ Berlinski dopisnik lista Aftonbladet izvještava jula 1942. da su Nijemci tog mjeseca pobili oko 2.000 Srba u Bosni. ${ }^{38}$ Stockholms Tidningen je 11. oktobra 1942. pisao da general Mihailović, „u svojoj ličnosti na srećan način ujedinjuje tradiciju srpskih boraca za slobodu sa svojim znanjem modernog oficira“. ${ }^{39}$ Desničarski Dagens Nyheter u broju od 22. februara 1943. navodi da od svih okupiranih zemalja, Jugoslavija stvara najveće poteškoće silama Osovine, jer odredi srpskog generala Mihailovića i od njega nezavisni partizanski odredi vezuju za sebe najmanje 30 njemačkih divizija. List dodaje da je u zemlji, koja je u krvavom haosu, do kraja 1942. godine ubijeno, po italijanskim izvorima, 823.000 Srba. ${ }^{40}$ Dagens Nyheter bio je naklonjeniji generalu Mihailoviću, za koga je 9. avgusta 1943. rečeno da su Nijemci ucijenili njegovu glavu na 100.000 zlatnih maraka. ${ }^{41}$ Isti list pisao je 14. decembra 1943. o razvoju događaja u Jugoslaviji nakon Teheranske konferencije, prenijevši vijest da je general Tito, vođa jugoslovenskih partizana, proglašen za predsjednika jugoslovenske vlade u zemlji i da ta vlada nema nikakvog obzira prema jugoslovenskoj vladi u izbjeglištvu i prema kralju Petru II Karađorđeviću. ${ }^{42}$ Vijesti su prenošene posredstvom agencije Tidningarnas Telegrambyra. ${ }^{43}$

Po službenim podacima švedskih vlasti, u Švedskoj je 1941. godine bilo 19 jugoslovenskih državljana, uključujući i osoblje poslanstva. ${ }^{44}$ Taj broj postepeno je rastao zbog priliva jugoslovenskih bjegunaca iz nacističkih logora u Norveškoj. Naime, tokom Drugog svjetskog rata, Nijemci su internirali u svoje logore u Norvešku 4.268 ljudi iz Jugoslavije, od čega 3.841 Srba, 179 muslimana, 165 Hrvata i 83 ostalih. ${ }^{45}$ To su uglavnom bili

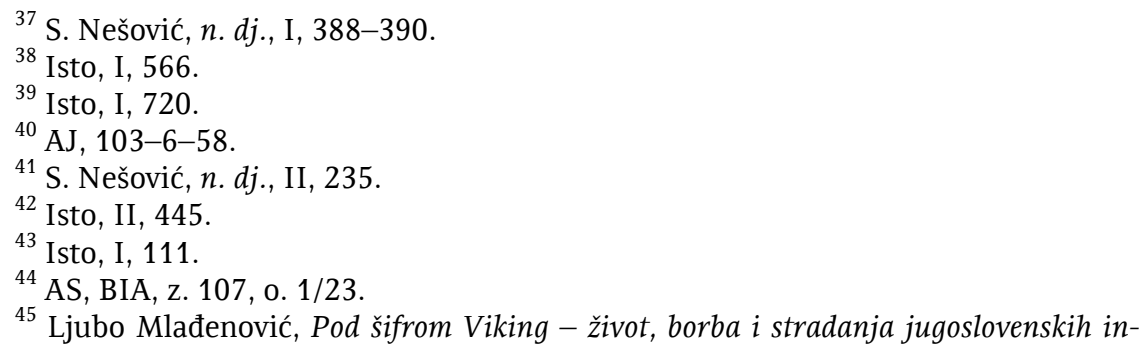
terniraca u logorima u Norveškoj 1942-1945: studijsko-dokumentarna monografija, Beograd 1991, 71. 
zarobljeni partizani, uhapšeni ilegalni radnici, kao i saradnici i simpatizeri oslobodilačkog pokreta. Oni su odvedeni u Norvešku, gdje je boravilo oko 350.000 njemačkih vojnika, zbog nacističke potrebe za radnom snagom, odnosno zbog gradnje saobraćajnica kroz sjevernu Norvešku, radi boljeg i pouzdanijeg snabdjevanja njemačkih trupa u Finskoj, kao i zbog gradnje utvrđenja duž norveške obale. Početkom 1942. godine, njemački rajhskomesar za Norvešku Jozef Terboven predložio je Vrhovnoj komandi da iz Jugoslavije u Norvešku bude dopremljeno nekoliko hiljada zatočenika na prinudni rad. Operacija prikupljanja ljudi i njihovog prebacivanja u sjevernu Norvešku nosila je naziv Viking. ${ }^{46}$ U Norvešku su pristizali u četiri grupe od 14. juna 1942. do 15. aprila 1943. godine, a iskrcavani su u Bergenu, Trondhejmu, Narviku i Oslu. ${ }^{47}$ Internirani Jugosloveni smješteni su u 30 logora u Norveškoj, od čega u 13 logora u sjevernoj Norveškoj (3.255 ljudi), u 13 logora u srednjoj Norveškoj (839), u tri logora u južnoj Norveškoj i Telemarku (145) i u jednom logoru u jugozapadnoj Norveškoj (27). Takođe, dvojica ljudi bili su na prinudnom radu na brodu u Norveškom moru. ${ }^{48}$ Neki internirci vraćeni su u Njemačku, a neki u Nezavisnu Državu Hrvatsku, 88 ih je pobjeglo u Švedsku, a kraj rata u nacističkim logorima u Norveškoj dočekao je 1.661 internirac. $^{49}$

Jugoslovenski internirci ginuli su na gradilištima, umirali od gladi i zime, masovno su strijeljani oni koji su bili bolesni i iznemogli, nesposobni za dalji rad, kao i oni koji su pokušali da pobjegnu. Najveći pokolj desio se u Bejsfjordu, gdje su nacisti za jednu noć, 17. na 18. juli 1942, strijeljali 287 interniraca. Kao razlog za masovnu likvidaciju navedena je pojava tifusa među logorašima ${ }^{50}$ Norveški učitelj, novinar i publicista Osmund Rerslet je krajem avgusta 1942. otišao u Švedsku i o pokolju u Bejsfordu obavijestio glavne švedske listove i neke strane agencije, a vijest je stigla i do norveške vlade $u$ Londonu. ${ }^{51}$

Norveški poslanik u Stokholmu Jens Bul obavijestio je Avakumovića u novembru 1942. da je sa švedskom vladom postignut sporazum da će tokom januara i februara 1943. švedski Crveni krst slati pakete norveškim građanima koji se nalaze u nacističkim logorima u Norveškoj. Bul je predložio da jugoslovenska vlada stupi u kontakt sa švedskom vladom i da preko nje pomogne jugoslovenskim internircima. Jugoslovenska vlada u izbjeglištvu prihvatila je ovaj prijedlog i ovlastila Avakumovića da započne pregovore

\footnotetext{
${ }^{46}$ Isto, 23.

${ }^{47}$ Isto, 36.

${ }^{48}$ Isto, 47, 69 .

${ }^{49}$ Isto, 69.

${ }^{50}$ Isto, 164.

${ }^{51}$ Isto, 489-490.
} 
sa švedskim vlastima. Pregovori su tekli dobro i izgledalo je da će jugoslovenski logoraši dobiti pomoć u hrani, odjeći i higijenskim sredstvima. Ipak, njemačke vlasti to nisu odobrile, tvrdeći da zarobljeni partizani nemaju status ratnih zarobljenika. ${ }^{52}$

U Švedsku je tokom 1942. godine prebjeglo 8 zarobljenika iz njemačkih logora u Norveškoj, a 1943. čak 53 logoraša. Njihov broj rastao je postepeno, tako da je 24. novembra 1943. u Švedskoj boravio 61 jugoslovenski državljanin. ${ }^{53}$ Nešto ranije, Avakumović je javio svojoj vladi da se poslanstvo u Stokholmu nalazi u sve težem položaju zbog sve većeg priliva izbjeglica, jer nije imao pravilnik o postupanju prema njima, kao ni odgovarajuća finansijska sredstva. Po prispjeću u Švedsku, tamošnje vlasti pružale su im prvu pomoć, a potom su obavještavale jugoslovensko poslanstvo, koje je preuzimalo brigu o njima. On je predložio da svaki jugoslovenski izbjeglica koji dođu u Švedsku dobije odijelo od 270 kruna i jednokratnu pomoć od 70 kruna, kao i da mu se pomogne u pronalaženju posla. Jugoslovenski poslanik javio je da je od 60 izbjeglica, njih 17 bolesno i nesposobno za rad. Avakumović se interesovao kod švedske vlade da li bi ona mogla da im plati odjeću, obuću, hranu, stan i liječenje, što bi Jugoslavija otplatila poslije rata. Načelni odgovor švedske vlade bio je pozitivan. Tokom 1944. godine $\mathrm{u}$ Švedsku je uspjelo da se prebaci 20 interniraca, a 1945. još sedmorica. Jugoslovenski državljani pristizali su u Švedsku uglavnom iz sjeverne i srednje Norveške. ${ }^{54}$ Po odluci jugoslovenske vlade, brigu o izbjeglicama u Švedskoj vodio je dr Ivan Šajković, generalni konzul u Helsinkiju, koji je izbjegao u Švedsku. Jugoslovensko poslanstvo u Stokholmu nastojalo je još aprila 1943. da kod švedskih vlasti izdejstvuje da Šajković, čiji je povratak u Finsku bio nemoguć, dobije posao lektora za srpski jezik na Univerzitetu u Upsali. $^{55}$

Kad se u švedskoj javnosti počelo ozbiljnije govoriti o teroru u nacističkim logorima u Norveškoj, njemački poslanik u Stokholmu zvanično je protestovao. Ipak, švedski ministar spoljnih poslova Kristijan Ginter u govoru koji je održao u švedskom parlamentu rekao je da su zbivanja u Norveškoj izazvala snažnu reakciju u Švedskoj, zato što je švedski narod zapanjen djelovanjem koje je u oštroj suprotnosti sa nordijskim osjećajem prava. ${ }^{56} \mathrm{U}$ stvari, u švedsko-njemačkim odnosima tokom Drugog svjetskog rata postoje dva perioda: prvi, u vrijeme velikog zamaha Njemačke, od početka rata do Staljingradske bitke 1942-1943. godine i drugi, u vrijeme njemačkog

\footnotetext{
52 Isto, 508-509.

${ }^{53} \mathrm{AJ}, 382-8-27$.

${ }^{54}$ AJ, 103-88-337.

${ }^{55}$ AJ, 382-1-8.

${ }^{56}$ Lj. Mlađenović, Pod šifrom Viking..., 497.
} 
povlačenja na Istočnom frontu, kad se Švedska djelimično oslobodila pritiska. Nakon februara 1943. u velikoj mjeri je obustavljen njemački tranzitni saobraćaj preko Švedske, a smanjen je i izvoz gvozdene rude iz Švedske u Njemačku. ${ }^{57}$

Jugoslovenski bjegunci iz Norveške prokomunističkog opredjeljenja, iako rasuti u više gradova u Švedskoj, počeli su se organizovati, i to najprije u Enčepingu. ${ }^{58} \mathrm{U}$ tom gradu napisali su 10. oktobra 1943. proglas koji su predali vladama Švedske, Britanije, SAD i SSSR. ${ }^{59}$ Tokom 1943. godine, jugoslovenska vlada tri puta je razmatrala mogućnost da jugoslovenski bjegunci iz Norveške budu prebačeni iz Švedske u Britaniju, radi uključivanja u savezničke redove. Avakumović je to predlagao i zbog ideološkog sukoba sa njima, jer su se neke grupe otvoreno zalagale da jugoslovensku vladu $u$ izbjeglištvu treba smatrati nelegitimnom i da tu vladu ne treba priznati. U komunističkoj propagandi među jugoslovenskim izbjeglicama u Švedskoj posebno se isticao Jovan Pavlović, partizan iz Valjeva, koji je boravio u Norčepingu, odakle je stigao iz Trondhejma, pobjegavši iz njemačkog logora. Od 5. do 7. januara 1944. u Vigbiholmu kod Stokholma održan je sastanak na kojem je prisustvovalo 55 jugoslovenskih izbjeglica. Na skupu, koji su finansirali švedski ljevičari, donesena je rezolucija o osnivanju Udruženja Jugoslovena u Švedskoj „Slobodna Jugoslavija“ (Jugoslavernas Forening i Sverige „Frit Jugoslavien“), čije je sjedište bilo u Stokholmu, na adresi Skeppargatan 39/II. Jugoslovensko poslanstvo u Stokholmu nije imalo uvida u rezoluciju koja je donesena na osnivačkoj skupštini Udruženja, osim što je raspolagalo informacijom da su okupljene izbjeglice bile protiv jugoslovenske vlade u emigraciji i da nisu željeli nikakav kontakt sa njenim predstavnicima.

Na sastanku je upućen pozdrav „narodnoj vladi Jugoslavije“, a predvodnik ove grupe bio je Ervin Mandel, za kojeg su u jugoslovenskom poslanstvu u Stokholmu tvrdili da je bivši jugoslovenski državljanin i vojni dezerter, a još su pretpostavljali da je i Jevrejin. Organ Švedske socijaldemokratske partije Morgon Tidningen pisao je 8. januara 1944. da u Švedskoj živi oko 60 Titovih partizana i da su održali prvi sastanak. Oni su prošli kroz pakao u Norveškoj i u životu je ostalo još samo 300 njih, navodi se u članku. O tom sastanku pisao je i Ny Dag, koji izveštava da je skup organizovala Švedska zemaljska radnička organizacija. Švedske vlasti nisu se miješale u političko opredjeljenje jugoslovenskih izbjeglica. ${ }^{60}$

${ }^{57}$ Stig Hadenius, Swedish Politics during the $20^{\text {th }}$ Century - Conflict and Consensus, Stockholm $1999^{5}, 66$.

\footnotetext{
${ }^{58}$ AJ, 382-15-53.

${ }^{59}$ Lj. Mlađenović, Pod šifrom Viking..., 609.

${ }^{60}$ AJ, 103-186-652.
} 
Zadaci Udruženja „Slobodna Jugoslavija“, čiji je predsjednik bio Boško Pažin, bili su: 1. Razvijanje aktivnosti u skladu sa odlukama Antifašističkog vijeća narodnog oslobođenja Jugoslavije, tj. komunističkog revolucionarnog pokreta u Jugoslaviji, 2. Borba protiv pristalica generala Mihailovića i jugoslovenske vlade u izbjeglištvu, 3. Povezivanje sa ideološki i programski srodnim organizacijama u Švedskoj, i 4. Uspostavljanje veza sa jugoslovenskim internircima koji su ostali u Norveškoj. Sa takvim programskim načelima, Udruženje nije moglo biti u dobrim odnosima sa Avakumovićem, koji je bio odan jugoslovenskoj vladi u izbjeglištvu i svom školskom drugu generalu Mihailoviću. Svoje opredjeljenje generalu Mihailoviću otvoreno su izrazila samo dvojica bjegunaca iz Norveške: Dušan Dutina i Veličko Bogdanović. ${ }^{61}$

Udruženje „Slobodna Jugoslavija“ izdavalo je Informacioni list i za pet mjeseci štampano je 20 brojeva. Takođe, pokrenut je i Aktivista - list organizacije aktivista Jugoslovena u Švedskoj, i izdata tri broja, kao i dva broja časopisa za kulturna pitanja Novi svet. Udruženje je sarađivalo sa Norveškim udruženjem (Norsk Samfund) i Danskim udruženjem (Dansk Samfund), a pored zahtjeva njemačkog poslanika da rad „Slobodne Jugoslavije" bude zabranjen, švedske vlasti su se prema Udruženju odnosile korektno. $^{62}$

Jugoslovenski poslanik u Stokholmu obavijestio je 21. jula 1944. jugoslovensku vladu u izbjeglištvu da postoji mogućnost da oko 1.600 jugoslovenskih državljana iz njemačkih logora u Norveškoj u skorije vrijeme bude prebačeno u Švedsku. Jugoslovenska vlada raspolagala je podacima da je $\mathrm{u}$ nacističkim logorima u Norveškoj, oko polarnog kruga, zatočeno oko 5.000 jugoslovenskih interniraca i preduzela je sve potrebne mjere da oni koji budu prispjeli u Švedsku, budu prihvaćeni i potom prebačeni u Britaniju. Predsjednik Ministarskog saveta Kraljevine Jugoslavije i ministar inostranih dela Ivan Šubašić predložio je da jugoslovenskom poslanstvu u Stokholmu bude odobren kredit, kako bi jugoslovenski državljani bili adekvatno zbrinuti. ${ }^{63}$

Nakon dešavanja na jugoslovenskom ratištu 1943. godine jugoslovenska kraljevska vlada u izbjeglištvu, pod britanskim pritiskom, sklopila je sporazume sa jugoslovenskom komunističkom vladom u zemlji, čime su u velikoj mjeri prihvaćene tekovine komunističke revolucije u Jugoslaviji. Komunistički pokret nastojao je da zadobije međunarodno priznanje i da preuzme jugoslovenski diplomatski aparat, a promjene $u$ diplomatskoj mreži bile su moguće poslije sporazuma zaključenih na Visu 16. juna i u Beogradu

\footnotetext{
${ }^{61}$ Lj. Mlađenović, Pod šifrom Viking..., 609, 618, 638.

${ }^{62}$ Isto, 625-627.

${ }^{63}$ Jugoslovenske vlade u izbeglištvu 1943-1945: dokumenti, 362-363.
} 
1. novembra 1944. godine.$^{64}$ Kao posljedica tih sporazuma, više jugoslovenskih poslanika razriješeno je dužnosti, uključujući i Aleksandra Avakumovića, za koga je rečeno da je „Dražin čovek“ i da se „ponaša odvratno prema našim ljudima, koji beže iz Norveške“. ${ }^{65}$ On je penzionisan 12 . oktobra 1944, a u januaru iduće godine iz Stokholma je otišao u London. Odlaskom Aleksandra Avakumovića dužnost otpravnika poslova vršio je Nikola Nadić, savjetnik u jugoslovenskom poslanstvu, kome je Šubašić 22. januara 1945. pisao da djelovanje jugoslovenskog poslanstva treba uskladiti sa aktivnostima Udruženja „Slobodna Jugoslavija“, koje je od jugoslovenskog poslanstva postepeno preuzimalo ulogu jugoslovenskog predstavništva u Švedskoj. ${ }^{66}$ Od 120 jugoslovenskih izbjeglica u Švedskoj, među kojima je bilo i onih koji su stigli iz Njemačke i Finske, u Udruženju ih je bilo 82, dok je jugoslovenskoj vladi u izbjeglištvu ostalo vjerno njih $26 .{ }^{67} \mathrm{U}$ prvoj polovini 1945. godine u Švedskoj je bilo oko 210.000 izbjeglica, uglavnom iz skandinavskih i pribaltičkih zemalja koje su bile neposredno pogođene ratom, ${ }^{68}$ što znači da je broj Jugoslovena u ukupnom zbiru izbjeglica bio zanemarljivo mali.

Jugoslovenskom poslanstvu u Stokholmu obratilo se 9. marta 1945. petnaest Srba, izbjeglica u Švedskoj, koji su naveli da se Austrijanac Mandel bavi „problematičnim političkim djelatnostima“ i da je u Udruženje "Slobodna Jugoslavija“ okupio „kriminalne elemente“ i „njemačke agente“. Njih petnaest nisu željeli da se priključe Udruženju, zbog čega su ih komunisti „osudili na smrt". Oni su izrazili želju da se vrate u otadžbinu, ali preko Engleske. ${ }^{69}$

Na upražnjena poslanička mjesta novi jugoslovenski premijer i ministar inostranih poslova Ivan Šubašić postavljao je ljude iz Hrvatske seljačke stranke ili predratne građanske političare koji su bili podobni novim vlastima, a koji nisu morali nužno da budu ni Hrvati, niti komunisti. Tako je za novog jugoslovenskog poslanika u Švedskoj postavljen Rajko Đermanović $^{70}$ On je na tu dužnost imenovan 13. oktobra $1944,{ }^{71}$ a u Stokholm je stigao tek 2. juna 1945. godine. Poslaničku dužnost nije preuzeo od osoblja jugoslovenskog poslanstva nego od Udruženja „Slobodna Jugoslavija“, čije je

${ }^{64}$ Branko Petranović, Istorija Jugoslavije 1918-1988, I-III, Beograd 1988, II, 318-319.

${ }^{65}$ Slobodan Selinić, Promene u diplomatskim predstavništvima Jugoslavije 19441946, Istorija 20. veka, XXX, 3, Beograd 2012, 101.

${ }^{66}$ Ljubo Mlađenović, Pod šifrom Viking..., 639.

${ }^{67}$ Isto, 620, 641.

${ }^{68}$ Klas Åmark, Sweden and the Refugees 1933-1945, Reaching a State of Hope: Refugees, Immigrants and the Swedish Welfare State 1930-2000 (edited by Mikael Byström \& Pär Frohnert), Lund 2013, 39-40.

${ }_{70}^{69}$ RA, UD (1920 års dossiersystem), HP 563, XVI.

${ }^{70}$ D. Plenča, $n$. dj., 286.

${ }^{71}$ AJ, 382-12-38. 
djelovanje trajalo do kraja avgusta 1945. godine. Po Đermanovićevom dolasku, na zgradu poslanstva postavljeni su simboli nove Jugoslavije, ${ }^{72}$ a pročetničke grupe organizovale su demonstracije protiv njega. ${ }^{73}$ Protiv Đermanovića pisao je Dušan Dutina, vazduhoplovni poručnik. ${ }^{74}$

Jugoslovenski internirci u nacističkim logorima u Norveškoj dočekali su slobodu 8. maja 1945. godine. Grupa od 48 logoraša iz Osla otišla je u SSSR, a ostalih 1.613 ljudi ostalo je u Norveškoj još tri i po mjeseca. Oni su aktivno učestvovali u proslavama nacionalnog praznika Norveške 17. maja 1945. godine.$^{75} \mathrm{U}$ Trondhejmu je 15. juna 1945. formirana jugoslovenska vojna misija, na čijem čelu je stajao kapetan Nastas Bratić. Njegov zadatak bio je da obezbijedi vezu sa svim jugoslovenskim grupama u Norveškoj i da ih vrati u Jugoslaviju. Sve jugoslovenske skupine udružile su se u Partizanski odred bivših jugoslovenskih zarobljenika u Norveškoj. ${ }^{76} \mathrm{U}$ međuvremenu, neki od oslobođenih interniraca su umrli, a neki odlučili da ostanu u Norveškoj, tako da je 21. i 22. avgusta 1945. iz Melhusa ka Jugoslaviji krenulo njih $1.482 .{ }^{77}$ Petnaestak ih je ostalo u Norveškoj iz razloga privatne prirode, zbog ženidbe Norvežankama, a neki su ostali i zbog ideoloških neslaganja sa novim jugoslovenskim vlastima. Oko 100 ih je upućeno na liječenju na ostrvo Fresen kod Estersunda u Švedskoj. ${ }^{78}$ Ukupno je u njemačkim logorima u Norveškoj život izgubilo 2.396 jugoslovenskih interniraca, od čega 2.065 u sjevernoj Norveškoj. ${ }^{79}$

Jugoslovensko-švedski odnosi nastavljeni su nakon okončanja Drugog svjetskog rata u potpuno izmijenjenim međunarodnim okolnostima.

${ }^{72}$ S. Selinić, $n$. dj., 101.

${ }^{73}$ Lj. Mlađenović, Pod šifrom Viking..., 641.

${ }^{74}$ RA, UD (1920 års dossiersystem), HP 563, XVI.

${ }^{75}$ Lj. Mlađenović, Pod šifrom Viking..., 559-560.

${ }^{76}$ Isto, 581-583.

${ }^{77}$ Isto, 601-602.

${ }^{78}$ Milorad Ašković, Blagoje Marinković, Ljubomir Petrović, U logorima u severnoj Norveškoj, Beograd 1979, 335.

${ }^{79}$ Isto, 343. 
Goran Latinović

THE YUGOSLAV-SWEDISH RELATIONS 1941-1945

\section{Summary}

Despite the occupation and destruction of Yugoslavia in April 1941, the Yugoslav Legation in Stockholm, which had been opened in 1936, continued its activities as one of the diplomatic missions of the Yugoslav Government in exile. However, Yugoslav-Swedish relations during the Second World War were much less intense than in a pre-war period. Although Sweden did not officially recognize the Independent State of Croatia, they were maintaining mutual economic relations. The influx of Yugoslav refugees of pro-communist orientation to Sweden gradually led to their hostility with the Yugoslav Legation. Thus, the tragic civilian conflict, which was fiercely continuing in Yugoslavia, also transmitted to Sweden, although in a much less harmful way. There was another echo of the Yugoslav tragic events in Northern Europe. Of 4.268 men from Yugoslavia, mostly Serbs, who Nazis interned on forced labour in Norway, 2.396 of them lost their lives in German camps, while Sweden hosted 120 Yugoslav refugees. Advantageous relations of the Association „Free Yugoslavia“ and Swedish left-wing parties laid the foundations of Yugoslav-Swedish relations after 1945. 